DOI: 10.20472/IAC.2019.052.021

LIGIA MEIBOL FAJARDO VACA

UNIVERSIDAD ESTATAL DE MILAGRO, Ecuador

CARLOS EFRAIN VÁSQUEZ FAJARDO

UNIVERSIDAD ESTATAL DE MILAGRO, Ecuador

\title{
ETHICAL BEHAVIOR OF THE ACCOUNTANT AND ITS CONTRIBUTION TO THE SOCIETY
}

\begin{abstract}
:
The accountant in his professional act leads to various situations that, if not observed the provisions, legal statuses and apply their code of professional ethics, would face inherent risks that may transgress their professionalism and lose the faith and trust of the interested parties, who as social actors deposit in this type of professionals. The practice of this profession has been questioned deliberately throughout history, due to the evident cases of unethical behavior that affect not only business activities but also the financial situation of companies. Society in general has placed its trust in these professionals, to maneuver financial, accounting, tax, fiscal and control information. The audits that it executes allow to formulate audit findings related to the weaknesses of internal control, to express non-binding opinions, opinions that may or may not serve administrative judicial outcomes according to the circumstances arising from the requirement to develop their work, largely with responsibility and independence, with applicability of the rules of conduct, as a guarantee of transparency, that allows generating trust in companies and society. The objective of this research is to generate a reflexive analysis about the ethical behavior of the accounting professional and his contribution to society; it shows some ethical tools that can guide and facilitate the fulfillment of its delicate functions, they are regulated by fundamental principles and Ethics Rules that allow the strengthening of their public work in the profession. The type of study is qualitative, descriptive, and bibliographic. The main conclusions revolve around the importance of the ethics of the public accountant and the need to become aware, to acquire on a large scale the principles and rules of behavior, with primacy in their moral and personal values within their independent and professional actions, always oriented to the social function, always demonstrating its ethical integrity, morality, purity and justice, that of applying them contribute in a timely manner to the quality of life of society in general.
\end{abstract}

\section{Keywords:}

Ethical behavior, the accountant, responsibility, code of ethics

JEL Classification: M49, M41 